\title{
First records of Macromia katae (Macromiidae) and Indothemis carnatica (Libellulidae) from Vietnam (Insecta: Odonata)
}

\author{
Natalia von Ellenrieder ${ }^{1 *}$, Martin Hauser ${ }^{1}$, Stephen D. Gaimari ${ }^{1}$ and Thai H. Pham ${ }^{2}$ \\ 1 Plant Pest Diagnostics Center, California Department of Food and Agriculture, 3294 Meadowview Road, Sacramento, CA 95832-1448, USA \\ 2 Vietnam National Museum of Nature, Vietnam Academy of Science and Technology, 18 Hoang Quoc Viet Street, Cau Giay, Hanoi, Vietnam \\ * Corresponding author. E-mail: natalia.ellenrieder@gmail.com
}

\begin{abstract}
In the course of two field trips to Northern Vietnam during March 2012 and June 2014 the dragonflies and damselflies of three National Parks (Cuc Phuong, Tam Dao, and $\mathrm{Ba} \mathrm{Be}$ ) and one Biodiversity Station (Melinh) were sampled. A total of 90 species of odonates in 60 genera and 15 families was recorded, including two new records for Vietnam: Macromia katae (Macromiidae) and Indothemis carnatica (Libellulidae). Diagnostic illustrations for these two species are provided, as well as the listing of the species recorded from the surveyed areas.
\end{abstract}

Key words: Cuc Phuong, Tam Dao, Ba Be, Melinh

The odonate fauna of Vietnam was poorly known until relatively recently, based solely on scattered records and descriptions (i.e., Martin 1904, 1909; Ris 1912; Fraser 1926; Asahina 1969). In the late twentieth century a series of papers on the fauna of Northern Vietnam was published (Asahina 1995, 1996a, 1996b, 1996c, 1997a, 1997b, 1998; van Tol and Rozendaal 1995), and since then knowledge of this order in Vietnam increased exponentially. Do and Dang (2007) composed a checklist of the species known from the country, numerous new species descriptions and records were published by several authors (i.e. Do 2005, 2007, 2008, 2011a, 2011b, 2011c; Do and Bui 2011; Do and Karube 2011; Hämäläinen 2012, 2014a, 2014b; Hämäläinen and Karube 2001a, 2001b, 2013; Hämäläinen et al. 2006; Karube 2004, 2007, 2011a, 2011b, 2012, 2013, 2014a, 2014b; Phan and Hämäläinen 2011; Steinhoff and Do 2013), and two websites were created to aid in their field identification (Delonglée 2014; Kompier 2014).

In the course of two surveys in Northern Vietnam during March 2012 and June 2014, the dragonflies and damselflies of three National Parks (Cuc Phuong, Tam Dao, and Ba Be) and one Biodiversity Station (Melinh) were sampled. The odonates from some of these areas have been partially studied in the past; there is a list of the dragonflies (Anisoptera) from Cuc Phuong National Park (Do et al. 2011), and species descriptions from Tam Dao and Ba Be National Parks, but no records from Melinh Station.

In this paper we provide color scans, diagnostic illustrations, and notes for the two species that constitute new records for the country, as well as notes on four additional species which were reported in blogs from Vietnam but for which there are no published peer-reviewed records for the country yet, a checklist of all the species registered during this survey, field pictures of some of them, and a map showing the localities visited.

The four areas visited are located in Northern Vietnam. Cuc Phuong National Park, situated in the Red River Delta in Ninh Binh province, encompasses lowland primary forest extending between two limestone mountain ranges. Created in 1960 as a nature reserve, it was declared a National Park in 1962, and constitutes the oldest and largest National Park in Vietnam. Tam Dao National Park, in Vinh Phuc province, is located in a mountainous area including sharp peaks and steep slopes covered by primary and human altered forest. Melinh Station for Biodiversity, administered by the Institute of Ecology and Biological Studies of the Vietnam Academy of Science and Technology, is situated in the Me Linh district of Vinh Phuc province. Ba Be National Park, in Bac Kan province, was set up to protect a freshwater lake along with surrounding limestone and lowland evergreen forests. Cuc Phuong was visited during 25-26 March 2012 by S. Gaimari, M. Hauser, and T. Pham, and 12-17 June 2014 by N. von Ellenrieder, M. Hauser, and T. Pham. Tam Dao, Melinh, and Ba Be were sampled during June 2014 by N. von Ellenrieder, M. Hauser, and T. Pham.

Localities sampled (Figure 1) include:

1. Cuc Phuong, pond by road, $20^{\circ} 15^{\prime} 8^{\prime \prime} \mathrm{N}, 105^{\circ} 42^{\prime} 47^{\prime \prime} \mathrm{E}, 178$ $\mathrm{m}, 12-\mathrm{VI}-2014$; 15-VI-2014.

2. Cuc Phuong, Mac Lake, with sedges, grassy margins and flooded areas along road, $20^{\circ} 15^{\prime} 01^{\prime \prime} \mathrm{N}, 105^{\circ} 42^{\prime} 27^{\prime \prime} \mathrm{E}, 190 \mathrm{~m}$, 14, 16-17-VI-2014 (Figure 1).

3. Cuc Phuong, forested stream crossing road, $20^{\circ} 15^{\prime} 47^{\prime \prime} \mathrm{N}$, $105^{\circ} 42^{\prime} 2$ " E, $179 \mathrm{~m}, 16-\mathrm{VI}-2014$.

4. Cuc Phuong, forested stream crossing road, $20^{\circ} 16^{\prime} 46^{\prime \prime} \mathrm{N}$, $105^{\circ} 40^{\prime} 45^{\prime \prime}$ E, $242 \mathrm{~m}, 16-17-\mathrm{VI}-2014$.

5. Cuc Phuong, small sandy stream crossing road, $20^{\circ} 19^{\prime} 11^{\prime \prime}$ $\mathrm{N}, 105^{\circ} 37^{\prime} 43^{\prime \prime} \mathrm{E}, 258 \mathrm{~m}, 14-\mathrm{VI}-2014$.

6. Cuc Phuong, small dam and exit creek downstream with muddy bottom, $20^{\circ} 19^{\prime} 18^{\prime \prime} \mathrm{N}, 105^{\circ} 37^{\prime} 36^{\prime \prime} \mathrm{E}, 212 \mathrm{~m}$, 14-VI-2014.

7. Cuc Phuong, pool by secondary forest, $20^{\circ} 21^{\prime} 1^{\prime \prime} \mathrm{N}, 105^{\circ} 35^{\prime} 35^{\prime \prime}$ 


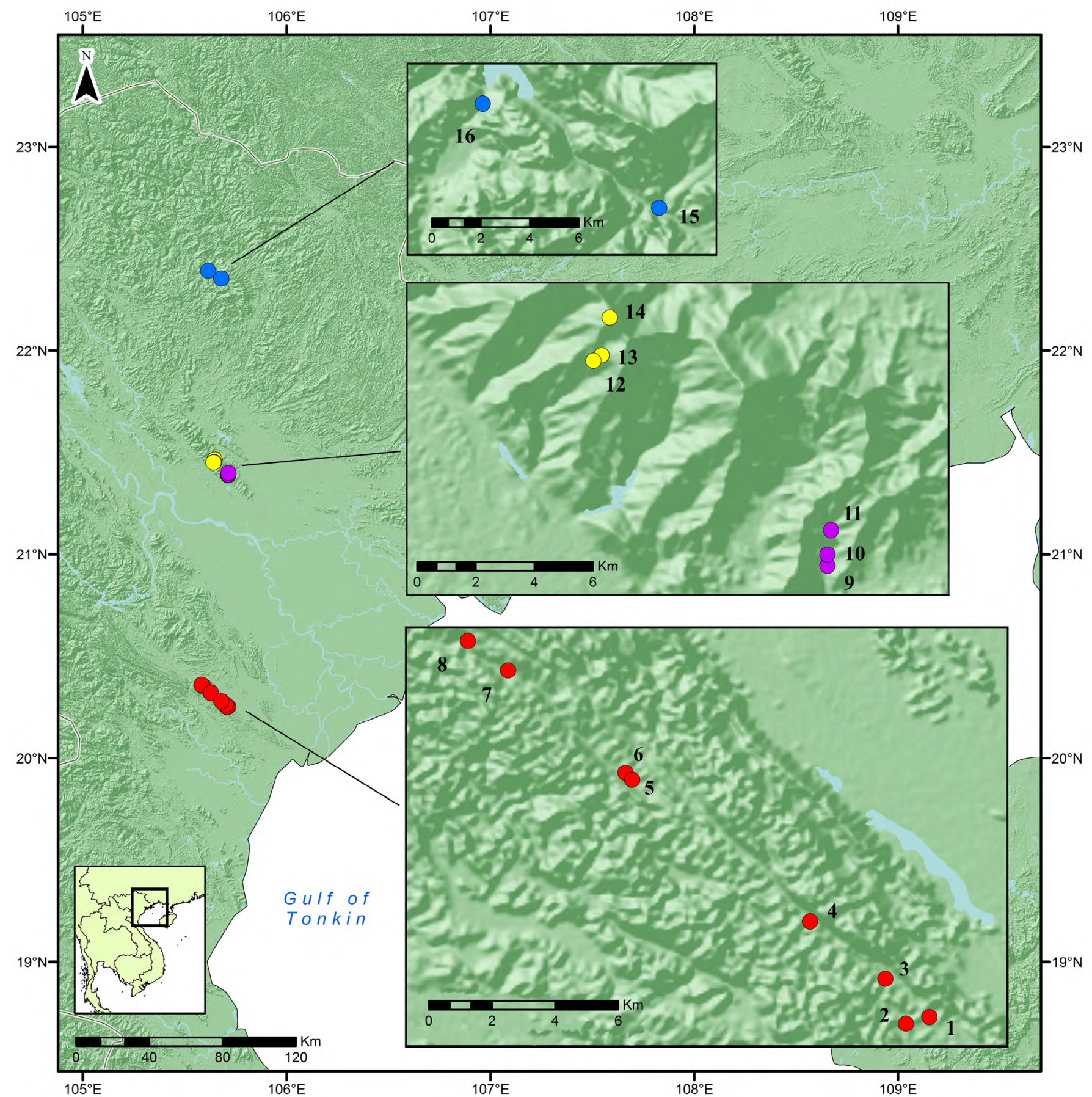

Figure 1. Localities visited in Northern Vietnam. 1-8: Cuc Phuong National Park; 9-11: Melinh Station for Biodiversity; 12-14: Tam Dao National Park; 15-16: Ba Be National Park. For locality codens see the text.

E, 380 m, 25-26 March 2012; 13, 15-18-VI-2014 (Figure 2).

8. Cuc Phuong, rocky creek and bedrock stream crossing trail in primary forest, $20^{\circ} 21^{\prime} 33^{\prime \prime} \mathrm{N}, 105^{\circ} 34^{\prime} 55^{\prime \prime} \mathrm{E}, 413 \mathrm{~m}$, 14-15-VI-2014.

9. Melinh, stream of stony and gravel bed running through secondary forest, $21^{\circ} 23^{\prime} 18^{\prime \prime} \mathrm{N}, 105^{\circ} 42^{\prime} 46^{\prime \prime} \mathrm{E}, 70 \mathrm{~m}$, 23-VI-2014.

10. Melinh, stream of stony and gravel bed running through secondary forest, $21^{\circ} 23^{\prime} 30^{\prime \prime} \mathrm{N}, 105^{\circ} 42^{\prime} 46^{\prime \prime} \mathrm{E}, 83 \mathrm{~m}, 24$-VI2014 (Figure 3).

11. Melinh, stream of stony and gravel bed running through secondary forest, $21^{\circ} 23^{\prime} 57^{\prime \prime} \mathrm{N}, 105^{\circ} 42^{\prime} 50^{\prime \prime} \mathrm{E}, 113 \mathrm{~m}$, 25-VI-2014.
12. Tam Dao, Suoi Bac, by Belvedere Resort, $21^{\circ} 27^{\prime} 4^{\prime \prime} \mathrm{N}$, $105^{\circ} 38^{\prime} 28^{\prime \prime}$ E, $750 \mathrm{~m}, 20-21-\mathrm{VI}-2014$.

13. Tam Dao, Thac Bac, $21^{\circ} 27^{\prime} 10^{\prime \prime} \mathrm{N}, 105^{\circ} 38^{\prime} 37^{\prime \prime} \mathrm{E}, 860 \mathrm{~m}$, 19-VI-2014.

14. Tam Dao, hill path to radio tower, $21^{\circ} 27^{\prime} 52^{\prime \prime} \mathrm{N}, 105^{\circ} 38^{\prime} 46^{\prime \prime}$ E, 1,200 m, 19-VI-2014.

15. Ba Be, stream at Ban Pjec, $22^{\circ} 21^{\prime} 15^{\prime \prime} \mathrm{N}, 105^{\circ} 40^{\prime} 45^{\prime \prime} \mathrm{E}, 162$ m, 28-29-VI-2014.

16. Ba Be, Na Phoong river, $22^{\circ} 23^{\prime} 33^{\prime \prime} \mathrm{N}, 105^{\circ} 36^{\prime} 52^{\prime \prime} \mathrm{E}, 170 \mathrm{~m}$, 27-28-VI-2014.

Odonates were collected with aerial nets and are deposited at the California State Collection of Arthropods (CSCA) and 


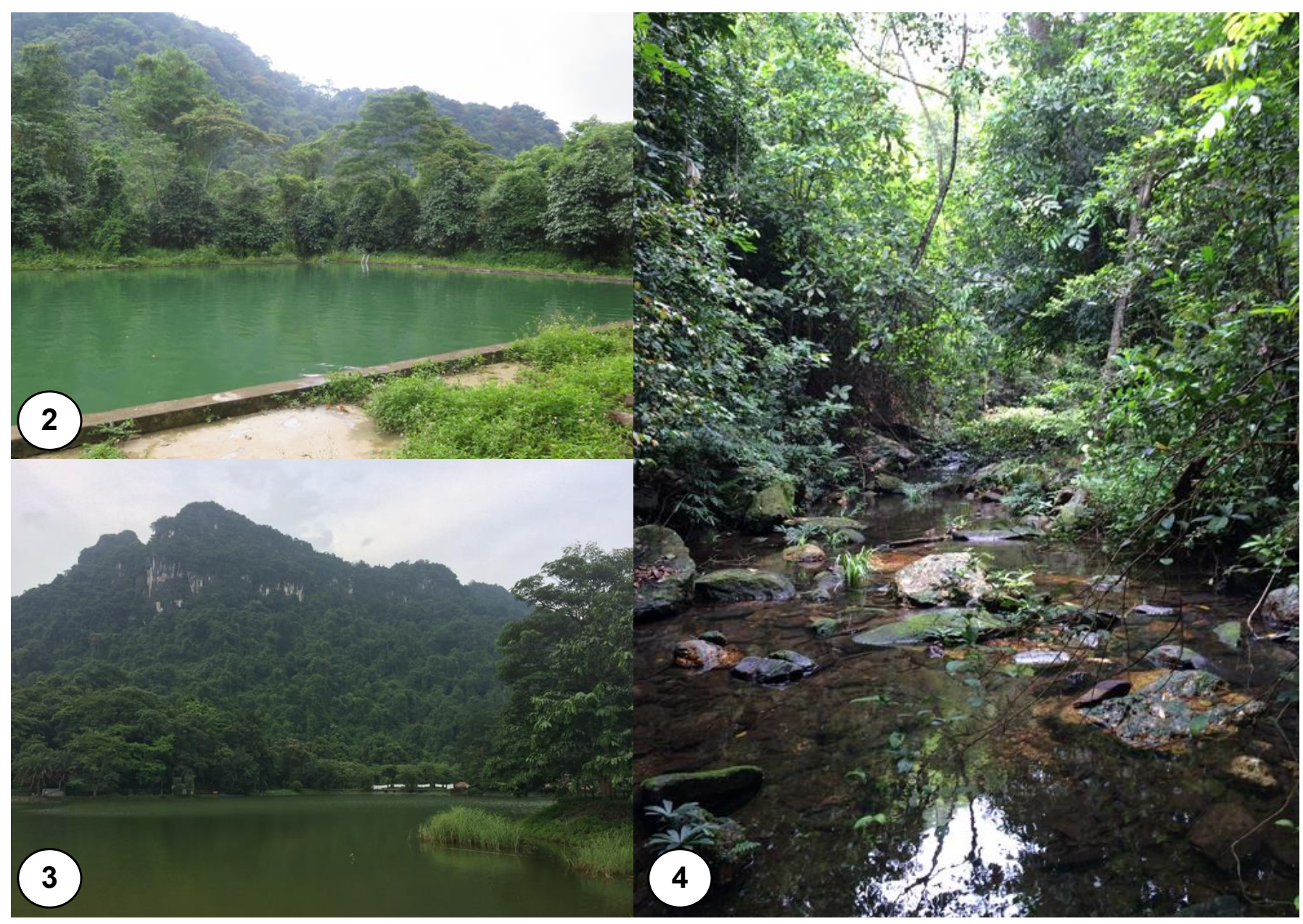

Figures 2-4. Habitat of the new records. 2: Pool at Cuc Phuong National Park (locality 7, by MH). 3: Mac Lake at Cuc Phuong National Park (locality 2, by NvE). 4: Stream at Melinh Station (locality 10, by NvE).

the Vietnam National Museum of Nature (VNMN). The classification followed is that outlined in Dikjstra et al. (2013). Color scans were done with an Epson Perfection 4870 scanner. Illustrations were composed using a camera lucida coupled to a Nikon SMZ15oo stereomicroscope, and are not to scale. The map was created electronically with ArcView 9.1.

Ninety species of odonates in 60 genera and 15 families were recorded, including 52 species from Cuc Phuong, 29 from Tam Dao, 27 from Ba Be, and 34 from Melinh (Table 1). Two of these species constitute new records for Vietnam:

\section{Macromia katae Wilson, 1993}

1 male from Melinh (locality 10); Figures 5-7

The presence of antehumeral stripes (Figure 5) and dorsum of abdominal segment 10 produced into a spine-like process (Figure 7) allows distinguishing this species from all other Macromia species recorded so far from China and Vietnam (Wilson 1993). The upright angle and structure of its posterior hamule and prominent perpendicular genital lobe (Figure 6) are shared with Macromia aculeata Fraser, 1927 described from Myanmar and recently recorded from Cambodia (Kosterin 2014a), and M. arachnomima Lieftinck, 1953 described from Borneo. Macromia katae differs from these two species (Fraser 1927; Lieftinck 1953; Wilson 1993; Kosterin 2014b) by its larger size, with abdomen including appendages $55 \mathrm{~mm}$ and hind wing 45-46.5 mm long (vs. abdomen 39-48 and hind wing 38-44 $\mathrm{mm}$ in the other two species), and color pattern of face with yellow spots at mandible bases, sides of labrum, and postclypeus (vs. indistinct yellowish areas at most). The presence of dark brown spots at wing bases also distinguishes M. katae from M. aculeata, which has no dark basal wing spots.

Macromia katae is so far only known from four localities within lowland secondary forest in China (Guangdong and Hainan) and Hong Kong, and in Laos near the Vietnam border (Yokoi 2003), and it has been assessed as Vulnerable by the IUCN Red List (Wilson 2013). It breeds exclusively in low gradient streams with moderate to fast flow, where the larva is found clinging to roots of mature, well established trees in stream pools or margins (Wilson and Theischinger 1996). Melinh Station encompasses 170.3 hectares of lowland secondary forest, crossed by several streams margined by well developed trees (Figure 4), providing an ideal habitat for the preservation of this species.

\section{Indothemis carnatica (Fabricius, 1798)}

2 males from Cuc Phuong (localities 2, 7); Figures 8-11

The original description of Indothemis carnatica was very brief and lacked any illustrations. After examining its holotype, Lieftinck (1971) synonymized it with I. caesia (Rambur, 1842), and published photographs of its wings, which allowed 
Table 1. Dragonflies and damselflies sampled at four protected areas in Northern Vietnam. @: new records for the country. For locality codens see the text.

\begin{tabular}{|c|c|c|c|c|c|c|}
\hline Family & Species & Cuc Phuong & Tam Dao & Melinh & $\mathrm{Ba} \mathrm{Be}$ & Year \\
\hline \multicolumn{7}{|l|}{ Zygoptera } \\
\hline \multirow[t]{2}{*}{ Platystictidae } & Protosticta grandis Asahina, 1985 & 8 & & & & 2014 \\
\hline & Protosticta satoi Asahina, 1997 (Figure 12) & 4,8 & 12,14 & & & 2014 \\
\hline Amphipterygidae & Devadatta ducatrix Lieftinck, 1969 (Figure 13) & & 12,13 & & & 2014 \\
\hline \multirow[t]{4}{*}{ Calopterygidae } & Atrocalopteryx coomani (Fraser, 1935) & & 12 & & & 2014 \\
\hline & Mnais mneme Ris, 1916 (Figure 14) & & & 10,11 & & 2014 \\
\hline & Neurobasis chinensis (Linnaeus, 1758) & 2,7 & & 9 & 15,16 & $2012 / 2014$ \\
\hline & Vestalis gracilis (Rambur, 1842) & & & & 15 & 2014 \\
\hline \multirow[t]{3}{*}{ Chlorocyphidae } & Aristocypha fenestrella (Rambur, 1842) (Figure 15) & 4 & 12,13 & 11 & & 2014 \\
\hline & Heliocypha perforata (Percheron, 1835) (Figure 16) & & & $9,10,11$ & 15,16 & 2014 \\
\hline & Libellago lineata (Burmeister, 1839) (Figure 17) & 2 & & & 16 & 2014 \\
\hline \multirow[t]{4}{*}{ Euphaeidae } & Cryptophaea vietnamensis (van Tol \& Rozendaal, 1995) (Figure 18) & 8 & 12,13 & 11 & & 2014 \\
\hline & Euphaea decorata Hagen in Selys, 1853 & & 12,13 & $9,10,11$ & 16 & 2014 \\
\hline & Euphaea guerini Rambur, 1842 (Figure 19) & & 12 & $9,10,11$ & & 2014 \\
\hline & Euphaea masoni Selys, 1879 (Figure 20) & & & 9 & 15 & 2014 \\
\hline Megapodagrionidae & Agriomorpha fusca May, 1933 (Figure 21) & $4,5,8$ & 12 & 10 & & 2014 \\
\hline Philogangidae & Philoganga vetusta Ris, 1912 & & 12 & & & 2014 \\
\hline \multirow[t]{13}{*}{ Platycnemididae } & Calicnemia mortoni (Laidlaw, 1917) (Figure 22) & & 12 & & & 2014 \\
\hline & Coeliccia acco Asahina, 1997 (Figure 23) & 4,8 & 12 & 10 & & 2014 \\
\hline & Coeliccia ambigua Asahina, 1997 (Figure 24) & & 12,14 & & & 2014 \\
\hline & Coeliccia cyanomelas Ris, 1912 & & 12,14 & & & 2014 \\
\hline & Coeliccia scutellum Laidlaw, 1932 (Figure 25) & 4 & 12 & 10 & 16 & 2014 \\
\hline & Coeliccia uenoi Asahina, 1997 & $4,7,8$ & & & & 2014 \\
\hline & Coeliccia sp. & 2,3 & & & & 2014 \\
\hline & Copera marginipes (Rambur, 1842) & $1,2,4,7$ & & 9,10 & 15 & $2012 / 2014$ \\
\hline & Copera vittata (Selys, 1863) & & & 10 & & 2014 \\
\hline & Indocnemis orang (Förster in Laidlaw, 1907) (Figure 26) & 4,8 & 12,14 & & & 2014 \\
\hline & Prodasineura autumnalis (Fraser, 1922) & 2,6 & & $9,10,11$ & 15,16 & 2014 \\
\hline & Prodasineura croconota Ris, 1916 & & & $9,10,11$ & & 2014 \\
\hline & Pseudocopera ciliata (Selys, 1863) & 7 & & & 16 & $2012 / 2014$ \\
\hline \multirow[t]{9}{*}{ Coenagrionidae } & Agriocnemis femina (Brauer, 1868) & 2 & & & & 2014 \\
\hline & Agriocnemis pygmaea (Rambur, 1842) & 7 & & & & 2012 \\
\hline & Ceriagrion auranticum Fraser, 1922 & 2 & & 10 & & 2014 \\
\hline & Ischnura senegalensis (Rambur, 1842) & 2,7 & & & & $2012 / 2014$ \\
\hline & Mortonagrion aborense (Laidlaw, 1914) & & & 9 & & 2014 \\
\hline & Paracercion calamorum (Ris, 1916) & $2,6,7$ & & & & $2012 / 2014$ \\
\hline & Paracercion melanotum (Selys, 1876) & 7 & & & & 2012 \\
\hline & Pseudagrion pruinosum (Burmeister, 1839) & & & & 16 & 2014 \\
\hline & Pseudagrion rubriceps Selys, 1876 & 2 & & & 15,16 & 2014 \\
\hline \multicolumn{7}{|l|}{ Anisoptera } \\
\hline \multirow[t]{7}{*}{ Aeshnidae } & Anax guttatus (Burmeister, 1839) & 7 & & & & 2014 \\
\hline & Gynacantha hyalina Selys, 1882 & 2 & & & & 2014 \\
\hline & Gynacantha japonica Bartenev, 1910 & 8 & & 9 & & 2014 \\
\hline & Gynacantha subinterrupta Rambur, 1842 & 1 & & & & 2014 \\
\hline & Periaeschna magdalena Martin, 1909 & & 12 & & 16 & 2014 \\
\hline & Planaeschna cucphuongensis Karube, 1999 & 8 & & & & 2014 \\
\hline & Tetracanthagyna waterhousei McLachlan, 1898 & 2 & & 9,10 & & 2014 \\
\hline
\end{tabular}


Table 1. Continued.

\begin{tabular}{|c|c|c|c|c|c|c|}
\hline Family & Species & Cuc Phuong & Tam Dao & Melinh & $\mathrm{Ba} \mathrm{Be}$ & Year \\
\hline \multirow[t]{15}{*}{ Gomphidae } & Asiagomphus acco Asahina, 1996 & 4 & & & & 2014 \\
\hline & Asiagomphus auricolor (Fraser, 1926) & & & 9,10 & & 2014 \\
\hline & Gomphidia kruegeri Martin, 1904 & & & $9,10,11$ & 15 & 2014 \\
\hline & Gomphidia sp. & & 12 & 10 & & 2014 \\
\hline & Heliogomphus retroflexus (Ris, 1912) & & & 10 & & 2014 \\
\hline & Heliogomphus scorpio (Ris, 1912) & 4 & & & & 2014 \\
\hline & Heliogomphus sp. & 4 & & & & 2014 \\
\hline & Ictinogomphus pertinax (Hagen in Selys, 1854) (Figure 27) & 2,7 & & & & 2014 \\
\hline & Leptogomphus perforatus Ris, 1912 (Figure 28) & & 12 & 9,10 & & 2014 \\
\hline & Megalogomphus sommeri (Selys, 1894) & 4 & & & & 2014 \\
\hline & Merogomphus tamdaoensis Karube, 2001 & & 12 & & & 2014 \\
\hline & Ophiogomphus sinicus (Chao, 1954) & & & 10 & & 2014 \\
\hline & Paragomphus capricornis (Förster, 1914) & & & & 15 & 2014 \\
\hline & Phaenandrogomphus tonkinicus (Fraser, 1926) & & & & 16 & 2014 \\
\hline & Sinictinogomphus clavatus (Fabricius, 1775) & 2 & & & & 2014 \\
\hline \multirow[t]{3}{*}{ Chlorogomphidae } & Chlorogomphus auratus Martin, 1910 & 4 & & & & 2014 \\
\hline & Chlorogomphus nakamurai Karube, 1995 & 4,5 & & & & 2014 \\
\hline & Chlorogomphus takakuwai Karube, 1995 & & 12,14 & & & 2014 \\
\hline \multirow[t]{3}{*}{ Synthemistidae } & Idionyx carinata Fraser, 1926 & & 12 & & & 2014 \\
\hline & Idionyx thailandica Hämäläinen, 1985 & & & 11 & & 2014 \\
\hline & Macromidia rapida Martin, 1907 & & & 9 & & 2014 \\
\hline \multirow[t]{5}{*}{ Macromiidae } & Epophthalmia elegans (Brauer, 1865) & 7 & & & & 2012 \\
\hline & Macromia clio Ris, 1916 & & & & 15 & 2014 \\
\hline & @ Macromia katae Wilson, 1993 & & & 10 & & 2014 \\
\hline & Macromia pinratani Asahina, 1983 & & 12,14 & & & 2014 \\
\hline & Macromia urania Ris, 1916 & & & & 16 & 2014 \\
\hline \multirow[t]{20}{*}{ Libellulidae } & Brachythemis contaminata (Fabricius, 1793) & 2,7 & & & & $2012 / 2014$ \\
\hline & Crocothemis servilia (Drury, 1773) & 7 & & & 16 & $2012 / 2014$ \\
\hline & Diplacodes trivialis (Rambur, 1842) & 7 & 14 & 10 & & $2012 / 2014$ \\
\hline & @ Indothemis carnatica (Fabricius, 1798) & 2,7 & & & & 2014 \\
\hline & Lyriothemis bivittata (Rambur, 1842) & & & 16 & 2014 & \\
\hline & Neurothemis fulvia (Drury, 1773) (Figure 29) & 2 & & & 16 & $2012 / 2014$ \\
\hline & Onychothemis tonkinensis Martin, 1904 & & & & 15 & 2014 \\
\hline & Orthetrum glaucum (Brauer, 1865) & 2,7 & 13 & & & 2014 \\
\hline & Orthetrum pruinosum (Burmeister, 1839) & 2,7 & & 10 & 16 & $2012 / 2014$ \\
\hline & Orthetrum sabina (Drury, 1770) & 2,7 & 12,14 & & 16 & $2012 / 2014$ \\
\hline & Orthetrum triangulare (Selys, 1878) & 4 & 14 & & & 2014 \\
\hline & Pantala flavescens (Fabricius, 1798) & 7 & 14 & 10 & & $2012 / 2014$ \\
\hline & Pseudothemis zonata (Burmeister, 1839) & 2,7 & & 11 & 15 & 2014 \\
\hline & Rhyothemis variegata (Linnaeus, 1763) & 2 & & & & 2014 \\
\hline & Tetrathemis platyptera Selys, 1878 & 6 & & & & 2014 \\
\hline & Trithemis aurora (Burmeister, 1839) & 2,7 & & 9,10 & 16 & $2012 / 2014$ \\
\hline & Trithemis festiva (Rambur, 1842) & 7 & & & 15 & $2012 / 2014$ \\
\hline & Zygonyx asahinai Matsuki \& Saito, 1995 & & 12 & & & 2014 \\
\hline & Zygonyx iris Selys, 1869 & & 12 & 9,11 & & 2014 \\
\hline & Total number of species & 52 & 29 & 34 & 27 & 90 \\
\hline
\end{tabular}




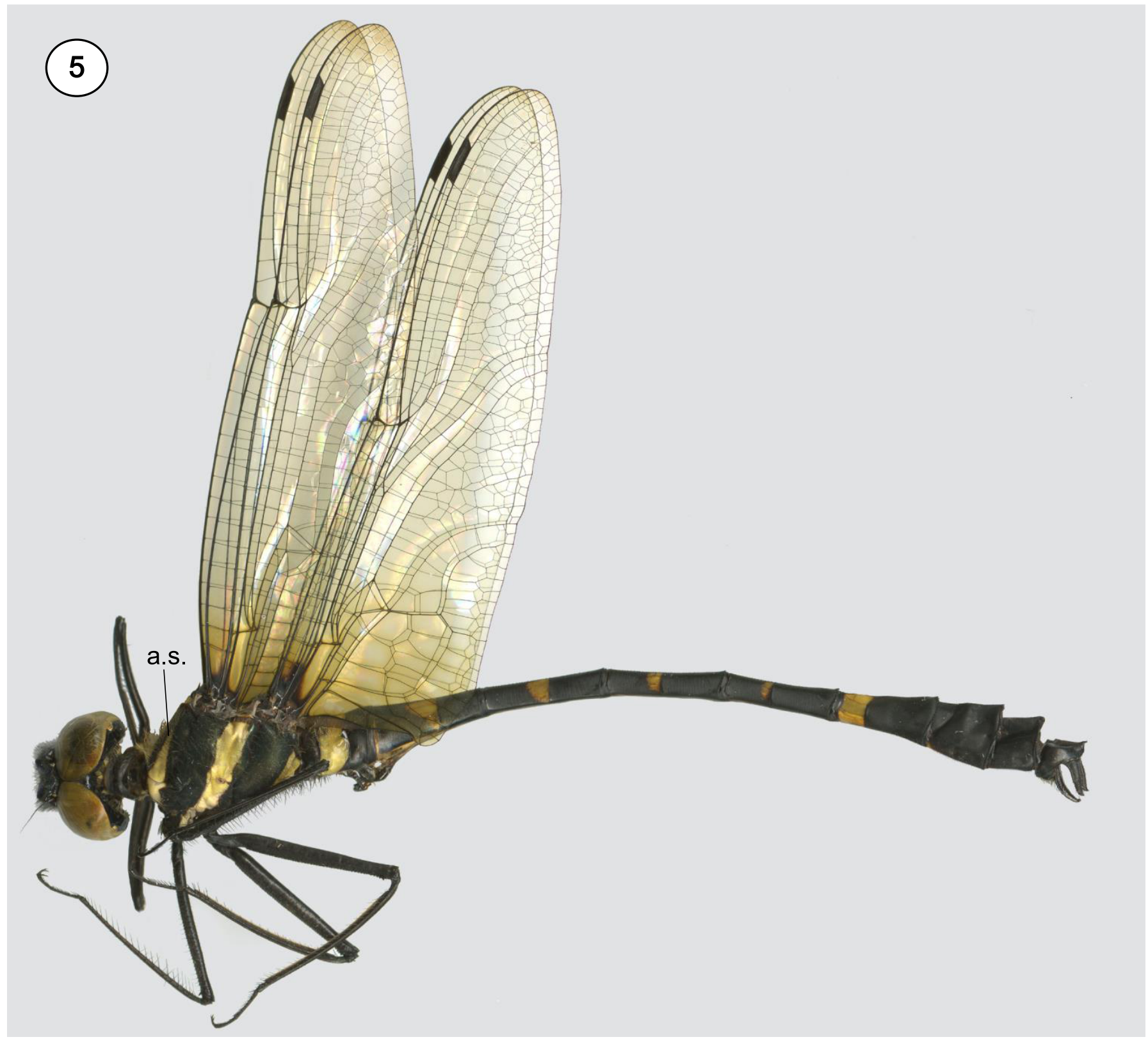

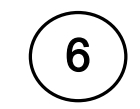

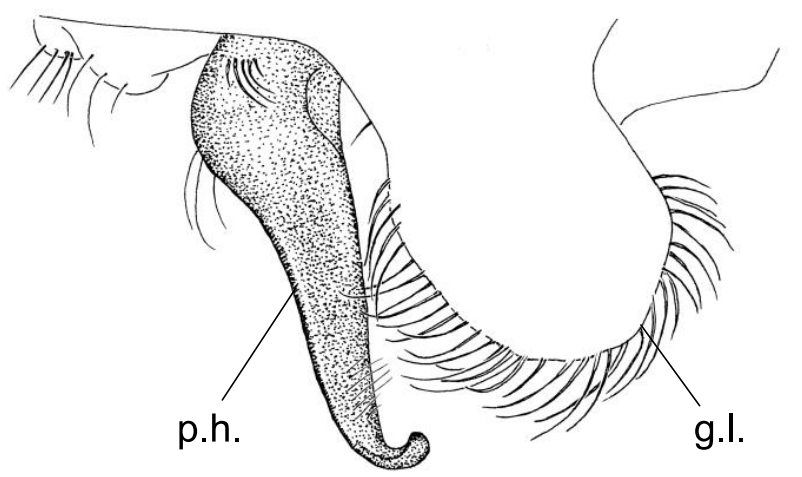

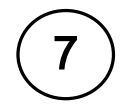

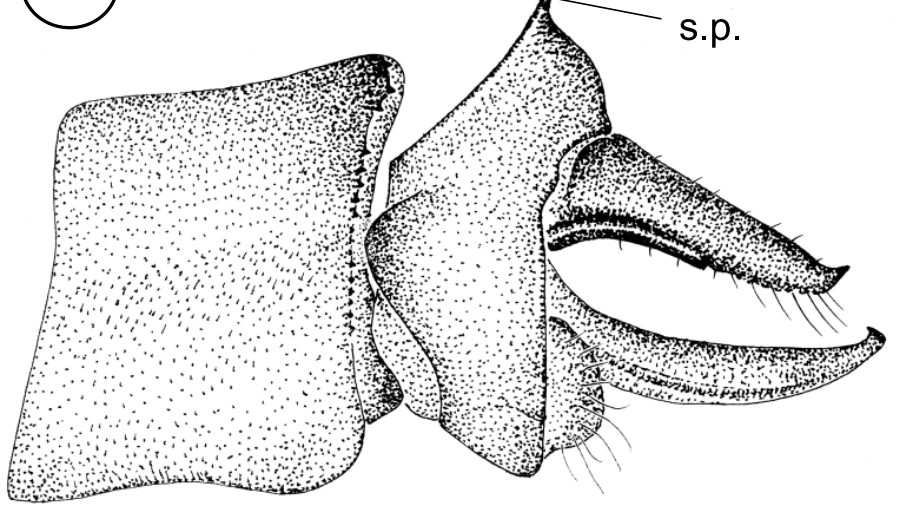

Figures 5-7. Macromia katae, male from Melinh Station for Biodiversity (locality 10). 5: Habitus scan. 6: Lateral view of genital fossa. 7: Lateral view of abdominal segments 9 and 10. a.h.: antehumeral stripe; g.l.: genital lobe; p.h.: posterior hamule; s.p.: spine-like process. 
us to confirm the identity of our specimens. The genus Indothemis currently includes only one additional species, I. limbata (Selys, 1891), which can be recognized from I. carnatica by differences in wing venation and color pattern (Fraser 1936). Here we provide color scans (Figures 8 and 9) and illustrations of some male body structures which are also of diagnostic value to distinguish both species and have never been figured before; in I. limbata the venter of thorax is only slightly swollen (distinctly swollen in I. carnatica, Figures 8 and 9) and inner branch of hamule is distinctly longer than outer branch (about as long as outer branch in I. carnatica, Figures 10 and 11).

Indothemis carnatica is apparently scarce and localized in occurrence, known from only a few locations in India, Sri Lanka, Thailand (Dow 2009), and Malaysia (Choong and Cheah 2013). Because of its limited range of distribution in areas altered by human development it was assessed as Near Threatened by the IUCN Red List (Dow 2009). The present

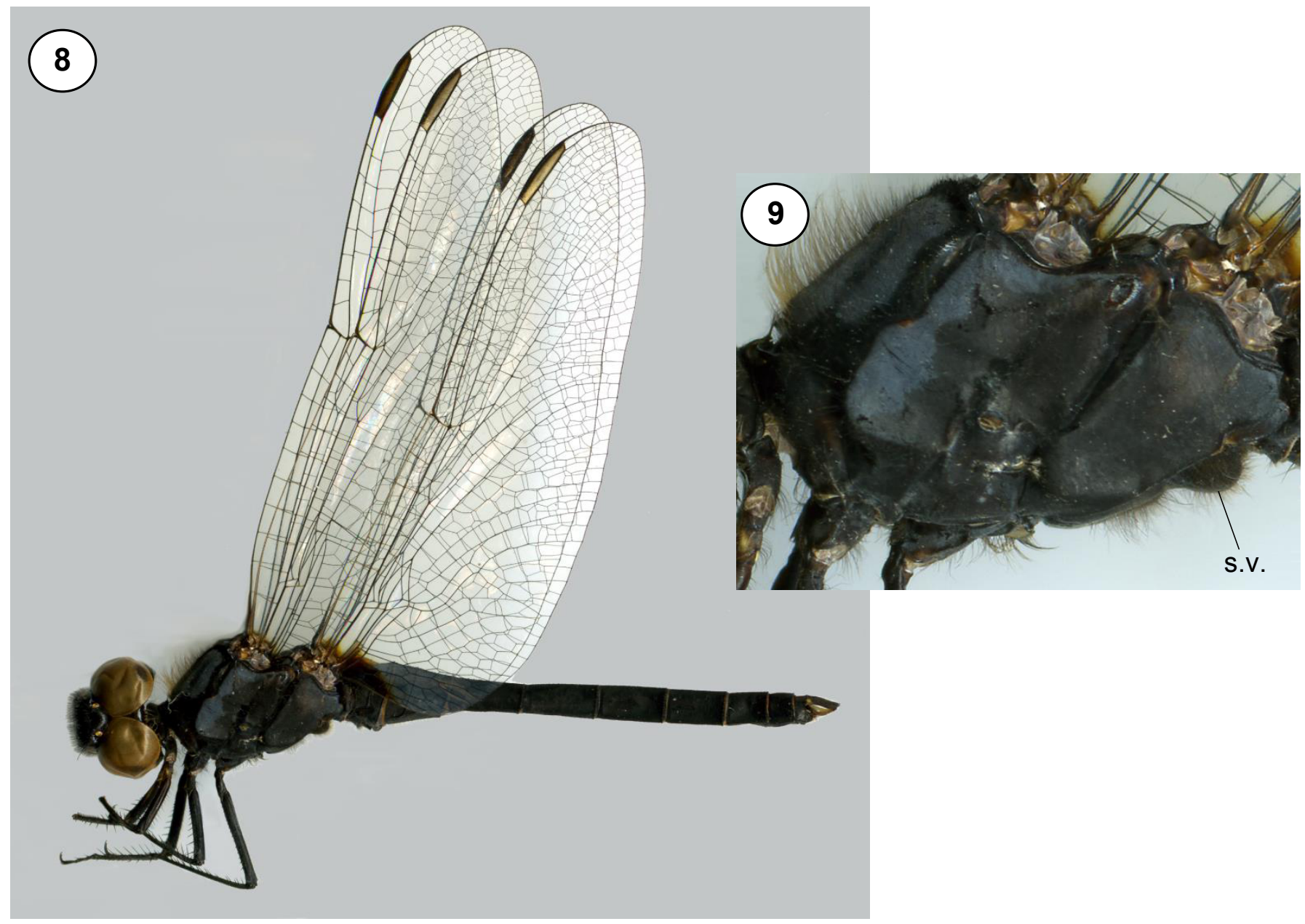

10

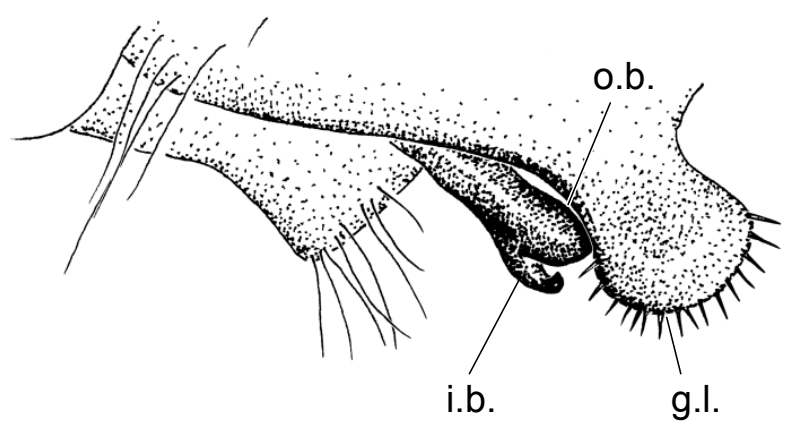

\section{1}

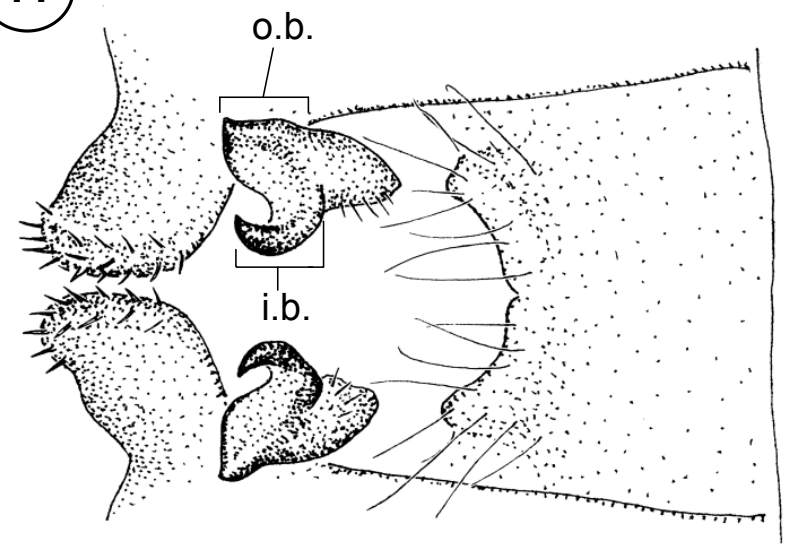

Figures 8-11. Indothemis carnatica, male from Cuc Phuong National Park (locality 2). 8: Habitus scan. 9: Lateral view of pterothorax. 10: Lateral view of male genital fossa. 11: Ventral view of male genital fossa. g.l.: genital lobe; i.b.: inner branch of hamule; o.b.: outer branch of hamule; s.v.: swollen thoracic venter. 


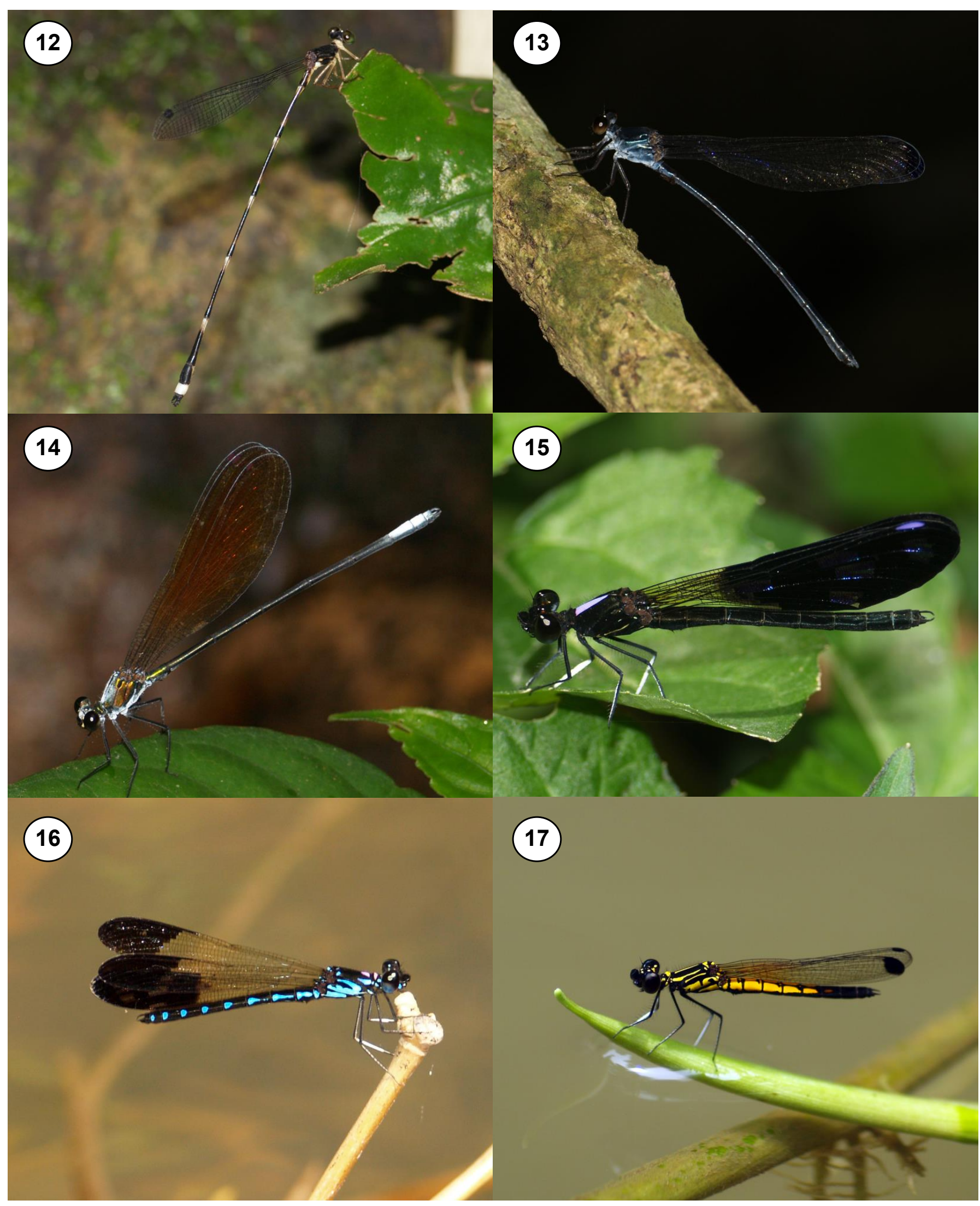

Figures 12-17. Live habitus pictures (by NvE). 12: Male of Protosticta satoi Asahina, 1997 at Tam Dao (locality 12). 13: Male of Devadatta ducatrix Lieftinck, 1969 at Tam Dao (locality 12). 14: Male of Mnais mneme Ris, 1916 at Melinh (locality 10). 15: Male of Aristocypha fenestrella (Rambur, 1842) at Tam Dao (locality 12). 16: Male of Heliocypha perforata (Percheron, 1835) at Ba Be (locality 16). 17: Male of Libellago lineata (Burmeister, 1839) at Ba Be (locality 16). 


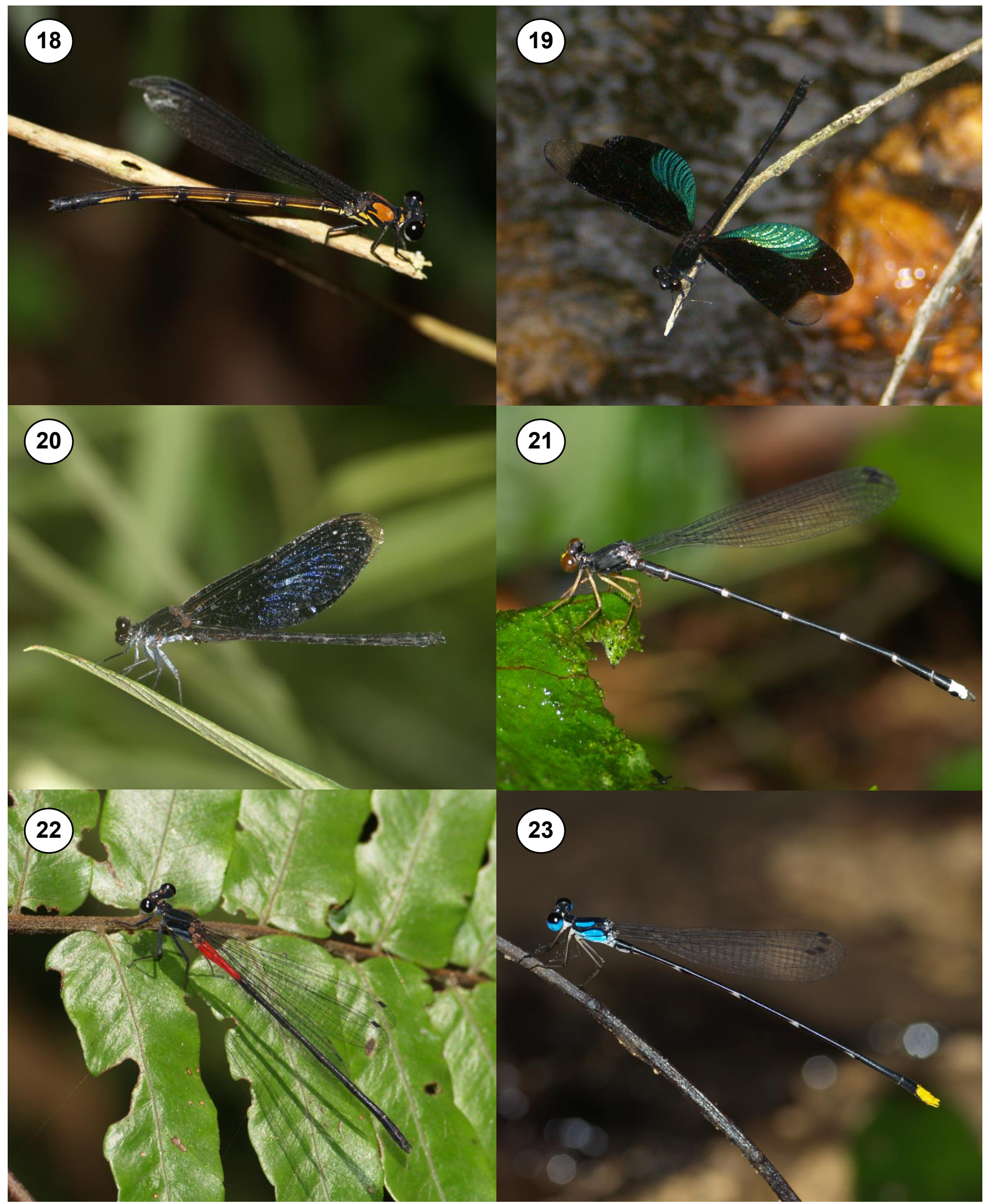

Figures 18-23. Live habitus pictures (by NvE). 18: Female of Chryptophaea vietnamensis (van Tol \& Rozendaal, 1995) at Tam Dao (locality 12). 19: Male of Euphaea guerini Rambur, 1843 at Melinh (locality 9). 20: Male of Euphaea masoni Selys, 1879 at Melinh (locality 9). 21: Male of Agriomorpha fusca May, 1933 at Cuc Phuong (locality 8). 22: Male of Calicnemia mortoni (Laidlaw, 1917) at Tam Dao (locality 12). 23: Male of Coeliccia acco Asahina, 1997 at Cuc Phuong (locality 8). 


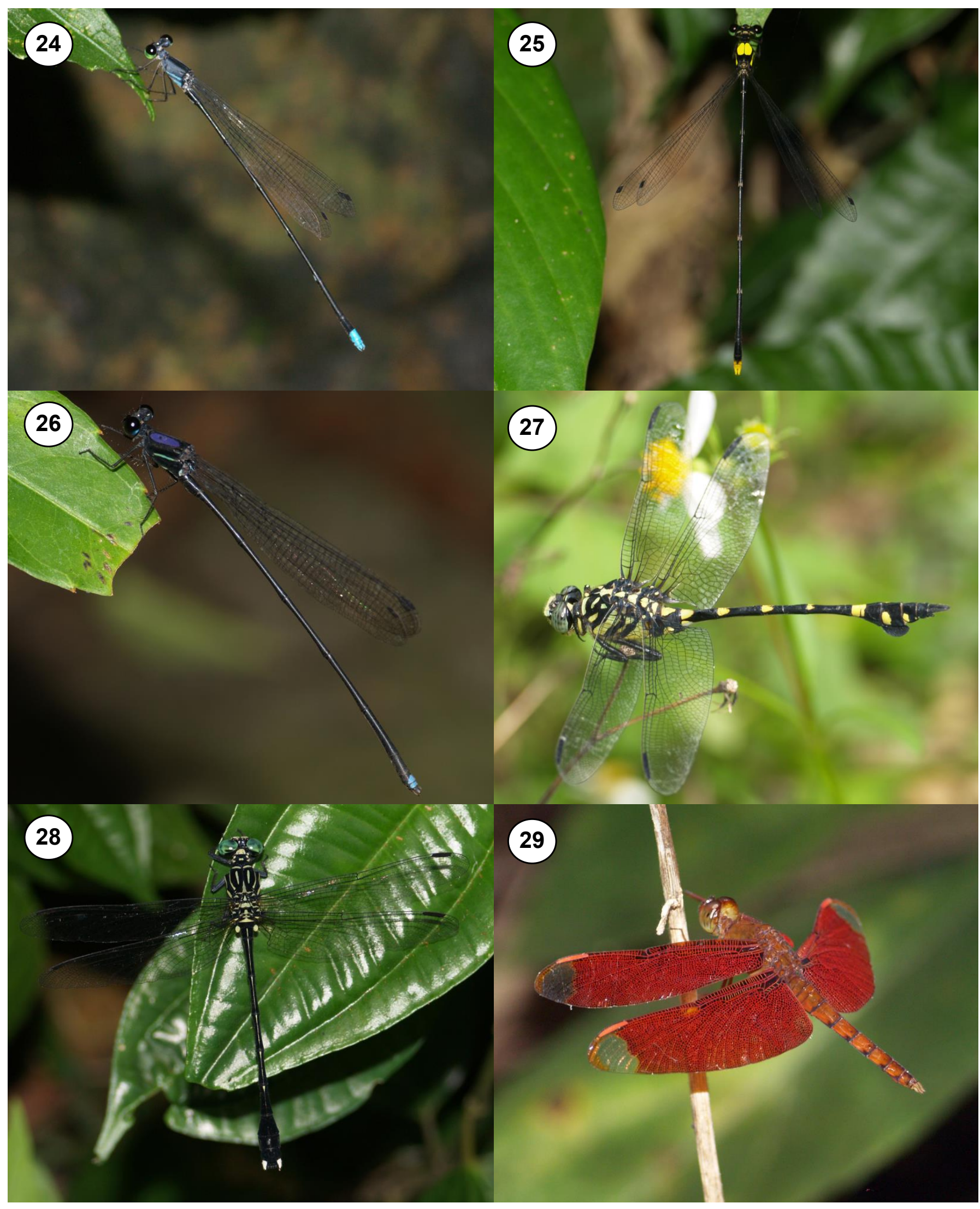

Figures 24-29. Live habitus pictures (by NvE). 24: Male of Coeliccia ambigua Asahina, 1997 at Tam Dao (locality 12). 25: Male of Coeliccia scutellum Laidlaw, 1932 at Tam Dao (locality 12). 26: Male of Indocnemis orang (Förster in Laidlaw, 1907) at Tam Dao (locality 12). 27: Male of Ictinogomphus pertinax (Hagen in Selys, 1854) at Cuc Phuong (locality 7). 28: Male of Leptogomphus perforatus Ris, 1912 at Tam Dao (locality 12). 29: Male of Neurothemis fulvia (Drury, 1773) at Ba Be (locality 16). 
finding extends its known area of occurrence considerably. This species breeds in small, heavily weeded ponds and lakes (Fraser 1936), and habitats suitable for its survival are currently protected within Cuc Phuong National Park (Figures 2 and 3 ).

Another four species found during this survey have been photographed and featured in blogs dealing with Vietnamese odonates (Delonglée 2014; Kompier 2014) but have not yet been recorded in peer-reviewed published literature. Our records for them are:

\section{Paracercion calamorum (Ris, 1916)}

6 males, 5 females from Cuc Phuong (localities 2, 6, 7)

Commonly found perching on floating water plants, this is a widespread species recorded from China, India, Indonesia, Japan, Korea, Nepal, Russia, and Thailand, and assessed as Least Concern by the IUCN Red List (Wilson 2009). Description and illustrations of male diagnostic caudal appendages can be found in Ris (1916: 29, 32-33, figure 9) and Dumont (2004: 364-365, figures 13-16)

\section{Mortonagrion aborense (Laidlaw, 1914)}

1 male, 1 female from Melinh (locality 9)

This is a species tolerant of disturbance which is found in forest streams, shady marshes, and ponds; it was recorded from India to Thailand and Laos, and south to Borneo and Sumatra, and assessed as Least Concern by the IUCN Red List (Subramanian 2010). Asahina (1982: 456-458, figures 1-10) provided a redescription and illustrations of diagnostic structures of males and females (as M. binocellata (Fraser, 1929), a junior synonym of this species).

\section{Ophiogomphus sinicus (Chao, 1954)}

1 male from Melinh (locality 10)

Known from several provinces in southeast China, this species was assessed as Data Deficient by the IUCN Red List due to the scarce knowledge about its habitat requirements and ecology (Tong 2013). This constitutes its first published record outside of China. Description and illustrations of diagnostic characters can be found in Chao (1954: 264-266, figures 438-444) and Karube (2014b: 88, figures 17a-c).

\section{Zygonyx asahinai Matsuki \& Saito, 1995}

1 female from Tam Dao (locality 12)

Matsuki and Saito (1995: 19-23, figures 1-19) described, diagnosed, and illustrated this species, which occurs in forested montane streams, including secondary forest, especially near waterfalls, and is known from several provinces in southeast China, having been assessed as Least Concern by the IUCN Red List (Wilson and Zhang 2013). This constitutes the first published record of this species outside of China.

Do et al. (2011) reported 19 species of Anisoptera for Cuc Phuong National Park. Here 37 species are added to the list for the Park, including 22 species of Zygoptera (see Table 1) and 15 of Anisoptera: Anax guttatus (Burmeister, 1839), Gynacantha hyalina Selys, 1882, G. japonica Bartenev, 1910, Heliogomphus scorpio (Ris, 1912), Heliogomphus sp., Epophthalmia elegans (Brauer, 1865), Brachythemis contaminata (Fabricius, 1793), Diplacodes trivialis (Rambur, 1842), Indothemis carnatica (Fabricius, 1798), Neurothemis fulvia (Drury, 1773), Orthetrum glaucum (Brauer, 1865), Pantala flavescens (Fabricius, 1798), Pseudothemis zonata (Burmeister, 1839), Trithemis aurora (Burmeister, 1839), and Trithemis festiva (Rambur, 1842).

Gynacantha hyalina was recorded from 'Tonkin' (Northern Vietnam) by Martin (1909), and never again mentioned from Vietnam in the literature. Lieftinck (1960: 251-252; figures 12a, b) examined the types of both $G$. hyalina and its most similar congener G. subinterrupta. He confirmed that the illustrations and species concepts in Martin (1909) agreed with those of their original descriptions, diagnosed the two species from one another, and provided illustrations of the appendages of the male holotype of $G$. hyalina, which closely match those of the male specimen collected in the present study.

Coeliccia sp., Gomphidia sp., and Heliogomphus sp. (Table 1), most likely represent new species, although revisionary work including examination of types is necessary to confirm this.

\section{ACKNOWLEDGMENTS}

We are very grateful to all the people who accompanied and assisted us in the field: Bui Minh Nueh, Luong Xuan Hien (Cuc Phuong), Nguyen Duc Long (Tam Dao), and Quang Khe (Ba $\mathrm{Be}$ ), and to the personnel of Melinh Biodiversity Station for their hospitality. Our gratitude to Matti Hämäläinen, Rosser Garrison, and two anonymous reviewers for their comments on the manuscript, and to Oleg Kosterin for sharing pictures of the holotype of Macromia aculeata and his diagnostic observations on related species, which allowed confirmation of the identification of M. katae.

\section{LITERATURE CITED}

Asahina, S. 1969. South Vietnam Odonata taken by Mr Y.I. Chu. Japanese Journal of Zoology 10: 1-18, pl. 1 excl.

Asahina, S. 1982. A list of the Odonata from Thailand. Part I. Agrionidae. Kontyû 50(3): 454-466.

Asahina, S. 1995. Records of the northern Vietnamese Odonata taken by the expedition members from the National Science Museum, Tokyo, 1. Cordulegasteridae. Bulletin of the National Science Museum, Series A (Zoology) 21(4): 221-229.

Asahina, S. 1996a. Records of the northern Vietnamese Odonata taken by the expedition members from the National Science Museum, Tokyo, 2. Gomphidae. Bulletin of the National Science Museum, Series A (Zoology) 22(1): 21-32.

Asahina, S. 1996b. Records of the northern Vietnamese Odonata taken by the expedition members from the National Science Museum, Tokyo. 3. Aeschnidae [sic], Corduliidae and Libellulidae. Bulletin of the National Science Museum, Series A (Zoology) 22(2): 69-80.

Asahina, S. 1996c. Records of the northern Vietnamese Odonata taken by the expedition members from the National Science Museum, Tokyo. 4. Libellaginidae, Euphaeidae, Calopterygidae and Amphipterygidae. Bulletin of the National Science Museum, Series A (Zoology) 22(4): 189-198.

Asahina, S. 1997a. Records of the northern Vietnamese Odonata taken by the expedition members from the National Science Museum, Tokyo. 5. Coenagrionidae, Protoneuridae and Platycnemididae. Bulletin of the National Science Museum, Series A (Zoology) 23(1): 17-34.

Asahina, S. 1997b. Records of the northern Vietnamese Odonata taken by the expedition members from the National Science Museum, Tokyo. 6. Platystictidae, Megapodagrionidae, Lestidae and Synlestidae. Bulletin of the National Science Museum, Series A (Zoology) 23(2): 107-113. 
Asahina, S. 1998. Further notes on Odonata from northern Vietnam. 1. Cordulegasteridae. Bulletin of the National Science Museum, Series A (Zoology) 24(1): 11-16.

Chao, H.-F. 1954. Classification of Chinese dragonflies of the family Gomphidae (Odonata), III. Acta Entomologica Sinica 4: 212-275.

Choong, C.Y. and S.L. Cheah. 2013. Odonata of Ayer Hitam Forest Reserve, Johor, Peninsular Malaysia. Faunistic Studies in SouthEast Asian and Pacific Island Odonata 2: 1-11.

Delonglée, S. 2014. VietOdonata. Accessible at http://vietodonata. blogspot.com. Captured on 14 August 2014.

Dijkstra, K.-D. B., G. Bechly, S.M. Bybee, R.A. Dow, H.J. Dumont, G. Fleck, R.W. Garrison, M. Hämäläinen, V.J. Kalkman, H. Karube, M. L. May, A.G. Orr, D.R. Paulson, A.C. Rehn, G. Theischinger, J.W.H. Trueman, J. van Tol, N. von Ellenrieder and J. Ware. 2013. The classification and diversity of dragonflies and damselflies (Odonata); pp. 36-45, in: Zhang, Z.-Q. (ed.). Animal Biodiversity: An outline of higher-level classification and survey of taxonomic richness (addenda 2013). Zootaxa 3703(1): 1-82 (doi: 10.11646/zootaxa.3703.1.9).

Do, M.C. 2005. Davidius monastyrskii spec. nov., a new dragonfly from northern Vietnam (Anisoptera: Gomphidae). Odonatologica 34(3): 285-289.

Do, M.C. 2007. Coeliccia hoanglienensis spec. nov., a new platynemid [sic] damselfly from Hoang Lien Mountains in the north of Vietnam (Zygoptera: Plastinemididae [sic]); pp. 343-348, in: B.K. Tyagi (ed.). Odonata: Biology of dragonflies. Jodhpur: Scientific Publishers.

Do, M.C. 2008. Noguchiphaea mattii sp. nov. from southern Vietnam (Odonata: Calopterygidae) International Journal of Odonatology 11(1): 21-26 (doi: 10.1080/13887890.2008.9748308).

Do, M.C. 2011a. Notes on three species of gomphid dragonflies from Vietnam (Odonata: Gomphidae). International Dragonfly Fund, Report 36: 1-9.

Do, M.C. 2011b. Coeliccia sasamotoi sp. nov. from Vietnam and Laos (Odonata: Platycnemididae). International Journal of Odonatology 14(3): 193-197 (doi: 10.1080/13887890.2011.607078).

Do, M.C. 2011c. Burmagomphus schneideri sp. nov., a new dragonfly from the south of Vietnam (Odonata: Gomphidae). International Journal of Odonatology 14(3): 223-231 (doi: 10.1080/13887890.2011.610268).

Do, M.C. and M.H. Bui. 2011. Updated checklist of suborder Anisoptera (Odonata) of Vietnam with some additional notes. Proceedings of the 1st National Scientific Conference of Vietnam Natural Museum System, Hanoi, April 2011: 353-361.

Do, M.C., M.H. Bui, T.H. Nguyen and Q.T Phan. 2011. Anisoptera from Cuc Phuong National Park, North Vietnam. International Dragonfly Fund, Report 33: 1-18.

Do, M.C. and T.H. Dang. 2007. Checklist of Dragonfly from Vietnam. Hanoi: Vietnam National University Publisher. 6+181 pp.

Do, M.C. and H. Karube. 2011. Nihonogomphus schorri sp. nov. from Huu Lien Nature Reserve, Lang Son Province, Vietnam (Odonata: Gomphidae). Zootaxa 2831: 63-68.

Dow, R.A. 2009. Indothemis carnatica. The IUCN Red List of Threatened Species. Version 2014.2. Accessible at http://www.iucnredlist.org. Captured on 14 August 2014.

Dumont, H.J. 2004. Distinguishing between the East-Asiatic representatives of Paracercion Weekers \& Dumont (Zygoptera: Coenagrionidae). Odonatologica 33(4): 361-370.

Fraser, F.C. 1926. Notes on a collection of dragonflies (order Odonata) from the Dutch East Indies and descriptions of four new species from the neighbouring continent. Treubia 8(3/4): 467-494.

Fraser, F.C. 1927. Descriptions of twenty new Indian dragonflies. Records of the Indian Museum 29: 63-90.

Fraser, F.C. 1936. The Fauna of British India, including Ceylon and Burma. Odonata. Vol. III. London: Taylor and Francis. xii + 461 pp.

Hämäläinen, M. 2012. Platycnemis doi sp. nov. from Huu Lien nature reserve in northern Vietnam (Odonata: Platycnemididae). International Journal of Odonatology 15(3): 223-228 (doi:
10.1080/13887890.2012.700503).

Hämäläinen, M. 2014a. Indocypha neglecta sp. nov. from northern Vietnam (Odonata: Chlorocyphidae). Odonatologica 43(1/2): 79-90.

Hämäläinen, M. 2014b. Atrocalopteryx auco spec. nov. from Vietnam, with taxonomic notes on its congeners (Odonata: Calopterygidae). Zootaxa 3793(5): 561-572 (doi: 10.11646/ zootaxa.3793.5.4).

Hämäläinen, M. and H. Karube. 2001a. Two new species of Caloptera damselflies from southern Vietnam (Zygoptera: Chlorocyphidae and Euphaeidae). Odonatologica 30(2): 209-215.

Hämäläinen, M. and H. Karube. 2001b. Rhinocypha orea spec. nov., a new damselfly from Vietnam (Odonata: Chlorocyphidae). Zoologische Mededelingen, Leiden 75(23): 405-408 (http://www. repository.naturalis.nl/document/45077).

Hämäläinen, M. and H. Karube. 2013. Description of Anisopleura bipugio sp. nov. from southern Vietnam (Odonata: Euphaeidae). Tombo-Acta Odonatologica Japonica 55: 51-55.

Hämäläinen, M., A. Sasamoto and H. Karube. 2006. Description of Devadatta cyanocephala sp. nov. from Vietnam (Zygoptera: Amphipterygidae). Tombo-Acta Odonatologica Japonica 48: 1-6.

Karube, H. 2004. Vietnamese Odonata collected in 1992-2003 surveys. I. Aeshnidae. Tombo - Acta Odonatologica Japonica 47: 1-11.

Karube, H. 2007. Occurrence of a new species of the genus Procordulia (Anisoptera, Corduliidae) from northern Vietnam. Tombo-Acta Odonatologica Japonica 50: 49-52.

Karube 2011a. Two new species of the family Aeshnidae (Anisoptera) from Central Vietnam. Tombo-Acta Odonatologica Japonica 53: 75-8o.

Karube, H. 2011b. Vietnamese Odonata collected in 1992-2003 surveys. II. Macromiidae and Corduliidae. Tombo-Acta Odonatologica Japonica 53: 81-91.

Karube, H. 2012. Vietnamese Odonata collected in 1992-2003 surveys. III. Cordulegastridae, genus Anotogaster with note on the its [sic] systematic grouping. Tombo-Acta Odonatologica Japonica 54: 55-69.

Karube, H. 2013. Survey of the Vietnamese Chlorogomphidae (Odonata), with special reference grouping. Tombo-Acta Odonatologica Japonica 55: 13-43.

Karube, H. 2014a. Vietnamese Odonata collected in 1992-2003 surveys. IV. Synlestidae. Tombo-Acta Odonatologica Japonica 56: 73-76.

Karube, H. 2014b. Vietnamese Odonata collected in 1992-2003 surveys. V. Gomphidae. Tombo-Acta Odonatologica Japonica 56: 77-90.

Kompier, T. 2014. Dragonflies and Damselflies of Vietnam. Photos and Discussions on Dragonflies of Vietnam. Accessible at http:// odonatavietnam.blogspot.com. Captured on 14 August 2014.

Kosterin, O.E. 2014a. Odonata of the south-west and north-east of Cambodia as studied in early rainy season of 2013. International Dragonfly Fund, Report 67: 1-94.

Kosterin, O.E. 2014b. Taxonomic and faunal notes on Macromia Rambur, 1842 (Macromiidae) from Cambodia, with synonymisation of M. cupricincta Fraser, 1924 and M. berlandi Lieftinck, 1941. Odonatologica in prep.

Lieftinck, M.A. 1953. New dragonflies (Odonata) from Borneo, with notes on their habits and larvae. Treubia 22(2): 381-406.

Lieftinck, M.A. 1960. On the identity of some little known southeast Asiatic Odonata in European Museums described by E. de Selys Longchamps with descriptions of new species. Memorie della Società Entomologica Italiana 38: 229-256.

Lieftinck, M.A. 1971. Odonata from Ceylon. Entomologica scandinavica (Supplement) 1: 188-207.

Martin, R., 1904. Liste des Névroptères de l'Indo-Chine; pp. 204-221, in: A. Pavie (ed.), Mission Pavie Indo-Chine 1879-1895. Études diverses. III. Recherches sur l'histoire naturelle de l'Indo-Chine orientale. Paris: Ernest Leroux. xxi + 549 pp.

Martin, R. 1909. Aeschnines [3]. Collections Zoologiques du Baron Edm. de Selys Longchamps. Catalogue Systématique et Descriptif 
20: 157-223, pls. v-vi excl.

Matsuki, K. and Y. Saito. 1995. A new Zygonyx from Hong Kong (Odonata, Libellulidae). Tombo-Acta Odonatologica 38(1/4): 19-23.

Phan, Q.T. and M. Hämäläinen. 2011. Matrona taoi spec. nov., a new damselfly species from northern Vietnam (Odonata: Calopterygidae). Zootaxa 2927: 63-68.

Ris, F. 1912. Libellulinen 6. Collections Zoologiques du Baron Edm. de Selys Longchamps. Catalogue Systématique et Descriptif 14: 701-836, pl.-VI-excl.

Ris, F. 1916. H. Sauter's Formosa-Ausbeute. Odonata (Mit Notizen über andere ostasiatische Odonaten). Supplementa Entomologica 5: 1-81, pls. I-iii excl.

Steinhoff, P.O.M. and M.C. Do. 2013. Notes on some Coeliccia species from Vietnam (Zygoptera: Platycnemididae). Odonatologica 42(4): 347-357.

Subramanian, K.A. 2010. Mortonagrion aborense. The IUCN Red List of Threatened Species. Version 2014.2. Accessible at http//www. iucnredlist.org. Captured on 14 August 2014.

Tong, X. 2013. Ophiogomphus sinicus. The IUCN Red List of Threatened Species. Version 2014.2. Accessible at http//www.iucnredlist.org. Captured on 14 August 2014.

van Tol, J. and F.G. Rozendaal, 1995. Records of Calopterygoidea from Vietnam, with descriptions of two new species (Zygoptera: Amphipterygidae, Calopterygidae, Chlorocyphidae, Euphaeidae). Odonatologica 24(1): 89-107.
Wilson, K.D.P. 1993. Notes on Macromia from Hong Kong, with a description of M. katae spec. nov. (Anisoptera: Corduliidae). Odonatologica 22(2): 233-241.

Wilson, K.D.P. 2009. Paracercion calamorum. The IUCN Red List of Threatened Species. Version 2014.2. Accessible at http//www. iucnredlist.org. Captured on 14 August 2014.

Wilson, K.D.P. 2013. Macromia katae. The IUCN Red List of Threatened Species. Version 2014.2. Accessible at http//www.iucnredlist.org. Captured on 14 August 2014.

Wilson, K.D.P. and G. Theischinger. 1996. Further notes on the Macromia Rambur from Hong Kong, with descriptions of the larvae (Anisoptera: Corduliidae). Odonatologica 25(3): 275-282.

Wilson, K.D.P. and H. Zhang. 2013. Zygonyx asahinai. The IUCN Red List of Threatened Species. Version 2014.2. Accessible at http// www.iucnredlist.org. Captured on 14 August 2014

Yokoi, N. 2003. A record of Odonata in central Laos. Aeschna 40: 33-35.

Authors' contribution statement: NvE, MH, SG, and TP collected the specimens, $\mathrm{MH}$ and $\mathrm{NvE}$ took the habitat photos, NvE photographed the specimens in the field, did the identifications, scans and illustrations, wrote the text, and composed the plates and map.

Received: September 2014

Accepted: October 2014

Editorial responsibility: Alonso Ramirez 